\title{
Penyuluhan Dan Penguatan Karakter Perilaku Kebersihan Dan Kesehatan Bagi Pekerja Sektor Informal Untuk Tetap Produktif Pada Saat Situasi Dan Kondisi Pandemi Covid 2019 Di Lasiana Kupang Ntt
}

\author{
${ }^{1}$ Muntasir Muntasir., ${ }^{2}$ Anderias Umbu Roga., ${ }^{3}$ Pius Weraman., ${ }^{4}$ Ketut Mahendra Kuswara, \\ ${ }^{5}$ S.P. Manongga., ${ }^{6} \mathrm{Jacob}$ M. Ratu. ${ }^{7}$ Teacher Manalu \\ ${ }^{1-6}$ Staf Pengajar Prodi Magister S2 IKM Pascasarjana UNC \\ ${ }^{7}$ Mahasiswa Prodi Magister Prodi Magister S2 IKM Pascasarjana UNC
}

Email : muntasir@staf.undana.ac.id; munbasrypps@yahoo.com

\begin{abstract}
Abstrak - Telah dilaksanakan aktivitas implementasi hasil riset bagi khalayak banyak dalam bentuk sosialisasi penyampaian materi pengetahuan ilmiah berupa penyuluhan dan penguatan perilaku kebersihan dan kesehatan bagi pekerja sektor informal agar tetap produktif pada saat situasi dan kondisi pandemi covid 2019 di lasiana kupang ntt telah dilaksanakan secara daya guna dan cermat. Metode pengabdian masyarakat dengan tahapan : 1) perencanaan dan desain kegiatan; 2) penyediaan material sesuai kebutuhan; 3) persiapan pra pelaksanaan dan pelaksanaan kegiatan; 4) penyampaian materi penyuluhan dan sosialisasi penguatan karakter perilaku kebersihan dan kesehatan bagi pekerja sektor informal untuk tetap produktif pada saat situasi dan kondisi pandemi covid 2019 di lasiana, kupang ntt; 5) tanya jawab dan curah pendapat serta saran dari pelaksana dan mitra sasaran; 6) Pemantauan lapangan oleh suvervisor monitoring; 7) penilaian hasil kegiatan aktivitas kemitraan masyarakat oleh tim supervisor dan 8) laporan akhir kegiatan. Luaran kegiatan ini adalah pengetahuan dan pemahaman bagi para pekerja sektor informal yang terdampak covid 2019 utamanya para kuli bangunan dan para pekerja tidak tetap yang berada di lasiana kota kupang, untuk selalu melakukan pola dan perilaku sehat utamanya perilaku hidup bersih dan sehat dan pemberian bantuan kemanusian dalam bentuk kebutuhan pangan, masker dan sabun pembersih tangan.
\end{abstract}

Kata Kunci :Penguatan, pekerja sektor informal, tetap produktif

\begin{abstract}
Activities of implementing research results for many audiences have been carried out in the form of socialization of the delivery of scientific knowledge material in the form of counseling and strengthening hygiene and health behavior for informal sector workers in order to remain productive during the situation and conditions of the 2019 Covid pandemic in Lasiana Kupang Ntt which have been carried out efficiently and carefully. . Community service method with the following stages: 1) planning and design of activities; 2) supply of materials as needed; 3) pre-implementation preparation and implementation of activities; 4) delivery of counseling materials and socialization of strengthening the character of hygiene and health behavior for informal sector workers to remain productive during the situation and conditions of the 2019 Covid pandemic in Lasiana, Kupang Ntt; 5) questions and answers and brainstorming and suggestions from implementers and target partners; 6) Field monitoring by monitoring supervisor; 7) results of evaluation from community partnership activities and 8) the final report of the activity. The output of this activity is knowledge and understanding for informal sector workers affected by Covid 2019, especially construction workers and temporary workers in Lasiana, Kupang city, to always carry out healthy patterns and behavior, especially clean and healthy living habits and provide humanitarian assistance in form of food needs, masks and hand sanitizer.
\end{abstract}

Keywords: Strengthening, informal sector workers, remain productive

\section{PENDAHULUAN}

Topik ini mengangkat judul penyuluhan dan penguatan karakter Perilaku kebersihan dan kesehatan bagi pekerja sektor informal untuk tetap produktif pada saat situasi dan kondisi pandemi Covid 2019 di Lasiana Kupang NTT. Tujuan spesifik dari pengabdian bagi masyarakat ini, yaitu ditujukan kepada pekerja informal yang terdampak wabah pandemi covid 19 yang tersebar di wilayah desa penfui timur, kelurahan lasiana dan sekitarnya. Kelompok masyarakat sasaran adalah para pekerja informal terdampak dan terbatas dalam berbagai hal seperti kesehatan, ekonomi dan lainnya. Diperlukan bantuan guna meningkatkan pengetahuan tentang upaya mitigasi bencana dalam menjaga kesehatan masyarakat, melalui penyuluhan pola hidup bersih 
dan sehat, pembagian sembako untuk mempetahankan gizi keluarga mereka. Agar tidak memunculkan bencana baru. "Hungry man becomes angry man sesuai penyataan Kepala BNPB. Program Ipteks ini telah dilaksanakan sesuai rencana pada bulan Agustus hingga Desember 2020.

Keputusan pemegang otoritas tertinggi kesehatan di negara Indonesia membuat keputusan sistem di rumah saja yaitu seluruh warga negara Indonesia diharuskan agar tetap beraktivitas dan melakukan pekerjaan di rumah tangga mereka. Akibat regulasi ini menyebabkan pekerja sektor informal yaitu tenaga kasar, dan buruh menjadi pengangguran dan berada di rumah, penghasilan dari gaji dipotong bahkan tidak mendapatkan penghasilan, dan lebih parahnya lagi adanya beberapa perusahaan melakukan merumahkan para pekerja padahal masih mampu melakukan pekerjaan di tempat kerjanya. Akibat dengan adanya corona virus disease 2019 menimbulkan dampak di berbagi sektor.

Dampak dan akibat corona virus disease 2019 pada sektor kesehatan, perekonomian dan berbagai sektor lainnya termasuk pada tenaga kerja. Kementerian tenaga kerja (Kemenaker) memberikan data pekerja atau sektor ketenakerjaan yang terdampak corona virus disease 2019 dengan beberapa kriteria antara lain : pekerja formal yang mengalami pemutusan hubungan kerja sebanyak 375.165 pekerja, pekerja formal yang dirumahkan sebanyak 1.032.960 pekerja, pekerja informal yang terdampak sebanyak 314.833 pekerja dan total pekerja sebanyak 1.722 .958 pekerja yang terdata. Selanjutnya kementerian tenaga kerja terus melakukan pengakuran data sekitar satu juta dua ratus ribu lebih pekerja lainnya lainnya [1], [2].

Pandemi Corona Virus Disease 2019 atau disingkat Pandemi Covid-19 diperkirakan mulai mewabah seluruh jagat pada akhir tahun. Pandemi Covid-19 dengan kelajuan tinggi akan menyebabkan kematian pada manusia yang terinfeksi. penyebaran pada manusia melalui persentuhan tubuh atau bagian tubuh lainnya dan menginfeksi melalui oral (mulut), alat indera penglihan dan indera penciuman [3]. Akhir bulan Desember tepatnya 31 desember 2019 Badan Kesehatan Dunia atau WHO berdasarkan investigasi menyebutkan bahwa China Country Office merilis data yang memuat informasi temuan kasus Pneumonia yang belum memiliki derivasi yang ditemukan di kota Wuhan-China. Hasil pelacakan WHO pada 7 januari 2020 memberikan infromasi lengkap bahwa Pneumonia yang tidak diketahui ini merupakan jenis baru dari Pneumonia yaitu corona virus yang dikenal covid-19 [4]. Pada awal minggu kedua Maret 2002 lembaga kesehatan dunia WHO memberikan keputusan bahwa menetapkan wabah penyakit menular Corona Virus Disease 2019 sebagai pandemi global dan memberikan keputusan bahwa Corona Virus Disease 2019 dengan status tingkat sangat mengkhawatirkan yang memiliki tingkat kecepatan pertumbuhan virus spektakuler mencapai 118.000 kasus di 114 negara dan mengakibatkan 4.291 orang meninggal dunia [4], [5].

Pada awal bulan maret 2020 Presiden Republik Indonesia, bapak Joko Widodo di istana kepresidenan Indonesia memberikan pernyataan bahwa Negara Indonesia menjadi negara yang mengalami dampak Pandemi Covid-19 dengan kasus yang menimpa dua warga Depok, Jawa Barat [6]. Indonesia sampai dengan 30 Mei 2020, jumlah pasien positif covid-19 yang terkonfirmasi sebanyak 25.216 pasien dengan puncak penambahan pasien positif pada tanggal 21 mei 2020 sebanyak 973 pasien [6].

Pandemi Covid-19 yang memiliki perkembangbiakan yang spektakuler dan cepat serta butuh waktu untuk diidentifikasi, Lembaga kesehatan dunia dan dunia Internasional harus bertindak efektif dan cermat sebagai antisipasi dengan membuat keputusan publik. Akibat dan dampak yang ditimbulkan oleh virus ini telah menyebabkan kondisi kedaruratan kesehatan masyarakat di berbagai negara (Kedaruratan Kesehatan Masyarakat) [7].

Sektor atau zona informal mempunyai peranan yang luas di negara-negara sedang berkembang (NSB), salah satunya adalah Indonesia. Zona informal adalah sektor yang tidak terorganisasi (unorganized), tidak teratur (unregulated), dan kebanyakan legal tetapi tidak terdaftar (unregistered). Zona Informal mempuyai konstribusi penting pada kehidupan sosial ekonomi di Kota Kupang [8].

Zona atau ektor Informal mempunyai peranan penting, menurut Keith Hart (1971) bahwa zona informal adalah bagian angkatan kerja di kota, berada di luar pasar tenaga kerja terorganisir. Selanjutnya Breman berpendapat bahwa : "Zona informal merupakan masa pekerja kaum miskin dengan tingkat produktivitasnya rendah dibanding pekerja di sektor modern di kota yang tertutup bagi kaum miskin ini [9]. Pedoman yang dapat digunakan tentang zona informal, yaitu : usia, tingkat pendidikan, dan jam kerja atau masa kerja sebagai indikator untuk mendiskripsikan karateristik pekerja zona informal. Dimana zona informal tidak mengenal batasan umur, pekerja sektor informal itu umumnya berpendidikan rendah dan jam kerja yang tidak teratur [10]. Pekerjaan di zona informal memiliki kecenderungan lebih mudah mendapatkan pekerjaan, juga mudah mendapatkan akan adanya risiko, risiko kerja yang terjadi akibat kelompok pekerja yang tidak terproteksi baik dari sisi ekonomi, sosial maupun politik [10]. Berdasarkan data Sakernas BPS bulan Agustus 2015, mempunyai 
$76,12 \%$ pekerja zona informal. Zona informal cenderung lebih mudah untuk diintervensi karena tidak berdasarkan pada kontrak kerja ataupun tunduk pada ketentuan peundang-undangan ketenagakerjaan, pekerja informal lebih mudah untuk diberhentikan. [11], [12].

Perguruan Tinggi Universitas Nusa Cendana (Undana) dalam hal ini tim pelaksana dari departemen atau prodi magister S2 IKM program pascasarjana Undana melakukan usaha untuk mengaplikasikan hasil tridarma dari bidang penelitian dengan mendesimasi hasil penelitian dengan mengaplikasikan pengetahuan dan keterampilan tentang cara menghasilkan produk, melakukan karya cipta produk dan menghasilkan barang dengan harga yang memuaskan [13]. Undana memiliki integritas kelembagaan yang mana harus mampu memberikan solusi dalam mengatasi persoalan masyarakat yang dari berbagai sektor kehidupan termasuk sosial, budaya, politik, ilmu pengetahuan dan seni dan sebagainya sebagaimana dalam tujuan strategis disebutkan Peningkatan kapasitas kelembagaan pengabdian masyarakat untuk mengaplikasi ipteks yang berorientasi PIP untuk meningkatkan kesejahteraan masyarakat [14]. Sehingga Universitas Nusa Cendana memiliki integritas kelembagaan sebagai wadah ilmiah pada jenjang pendidikan tinggi menghasilkan lulusan sarjana yang mempunyai integritas mengaplikasikan ilmu pengetahuan dan seni guna dalam rangka peningkatan status sosial ekonomi dan mempunyai arti penting dalam berbagai lingkup kehidupan [14]. Guna memberikan efektivitas dan efisiensi dalam kaitan peningkatan nilai tambah dan manfaat, maka dilakukan penerapan teknologi tepat guna yang merupakan implementasi dari pengabdian masyarakat dari lembaga perguruan tinggi [15].

Kegiatan ini bertujuan : 1. Memberikan Penyuluhan dan Penguatan Karakter Perilaku Kebersihan dan Kesehatan Bagi Pekerja Sektor Informal untuk tetap produktif pada saat situasi dan kondisi Pandemi Covid 2019 di Kelurahan Lasiana Kota Kupang; 2. Melakukan penyampaian informasi dan kegiatan sosialisasi tentang pentingnya Penguatan Karakter perilaku kebersihan dan kesehatan bagi pekerja sektor informal untuk tetap produktif; 3. Memberikan pemahaman akan dampak negatif bila tidak melakukan perilaku perilaku kebersihan dan kesehatan bagi pekerja sektor informal; 4 . Memberikan pemecahan masalah berupa bentuk tindakan pencegahan dan penanganan serta mitigasi yang tepat perilaku kebersihan dan kesehatan dan pemberian sembako bagi pekerja sektor informal untuk tetap produktif pada saat situasi dan kondisi Pandemi Covid 2019 di Kelurahan Lasiana Kota Kupang; 5. Memberikan motivasi untuk tetap waspada dan hati-hati dalam proteksi diri untuk melakukan perilaku perilaku kebersihan dan kesehatan bagi pekerja sektor informal untuk tetap produktif pada saat situasi dan kondisi Pandemi Covid 2019 di Kelurahan Lasiana Kupang. 6. Memberikan bantuan sosial kemanusiaan dalam bentuk pangan dan material kesehatan.

\section{METODE}

Adapun Metodologi pelaksanaan pengmas dirancang dengan metode ceramah dan penyuluhan dengan menampilkan media audio visual, demonstrasi, tanya jawab serta screening kesehatan dan kebersihan diri. Juga dengan mengkombinasi teknik kegiatan yang dimodifikasi dari Muntasir, dkk. [16], (Sahdan et al.,[17], Weraman et al.,2019 [18] dan Prabandari, F. [19] yang terdiri dari : 1) Melakukan rencana aksi dan desain kegiatan untuk diaplikasikan; 2) Penyediaan bahan dan alat pendukung kegiatan sesuai kebutuhan dan keputusan rapat tim; 3) Penyedian dan pengurusan lokasi dan tempat kegiatan dan persiapan pelaksanaan lainnya; 4) Prapelaksanaan kegiatan; 5) Atribut kegiatan berupa pemasangan spanduk dan pemberian softcopy materi penyuluhan; 6) Penyampaian materi penyuluhan dan penguatan karakter kebersihan dan kesehatan bagi pekerja sektor informal untuk tetap produktif pada saat situasi dan kondisi pandemi covid 2019 di kelurahan Lasiana Kota Kupang; 7) Tanya jawab dan diskusi antara pemateri, pelaksana dan mitra sasaran; 9) Pengawasan internal oleh tim monitoring; 10) Penilaian akhir pengabdian masyarakat oleh tim pelaksana dan 11) Pertanggungjawaban laporan Akhir Pengabdian Masyarakat.

\section{HASIL DAN PEMBAHASAN}

Kegiatan tridarma perguruan tinggi dalam bentuk program kemitraan masyarakat berupa pengabdian masyarakat ini telah dilaksanakan di RT 4 RW 10 Kelurahan Lasiana Kota Kupang dengan melibatkan masyarakat pekerja sektor informal yang berada di wilayah ini. Pelaksanaan kegiatan ini dilalui dengan tahapan perencanaan, pelaksanaan kegiatan dan evaluasi serta keberlanjutan sesuai metode pengabdian masyarakat.

Pelaksanaaan dilakukan pada pada tanggal 24 Oktober 2020 dalam beberapa sesi :

a. Sesi 1. K3 pada bidang kesehatan bagi pekerja sektor informal pada saat pandemi covid 2019 oleh Dr. Anderias Umbu Roga, M.Kes

b. Sesi 2. Pencegahan Covid dengan $3 \mathrm{M}$ oleh dr. Teacher Manalu, S.Ked

c. Sesi 3. Pola Hidup Sehat dan Makanan bergizi untuk menjaga imunitas tubuh dari penularan Covid 2019 oleh dr. Maria, S.Ked

d. Sesi 4. Penyerahan bantuan pangan dan material kesehatan berupaa Sembako, Obatobatan dan Vitamin, Masker dan Handsaniter 
bagi pekerja informal oleh Dr. Muntasir, S.Si, Apt. M.Si

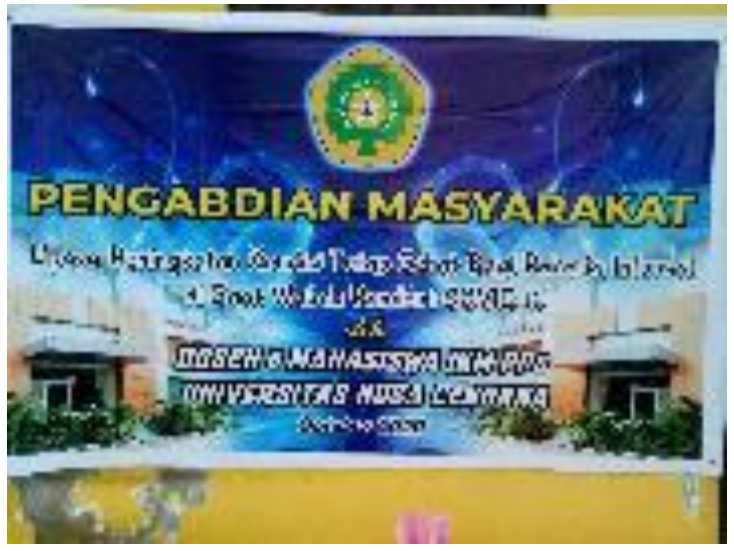

Gambar 1. Pemasangan spanduk di lokasi kegiatan

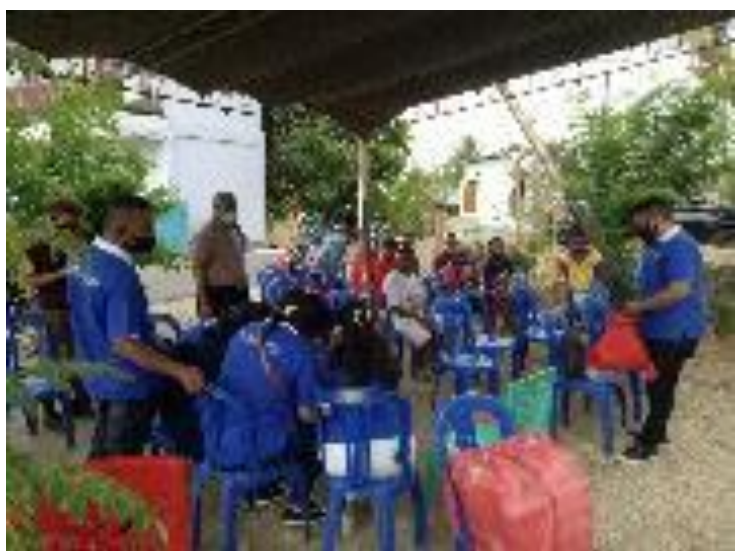

Gambar 2. Persiapan tim pelaksana
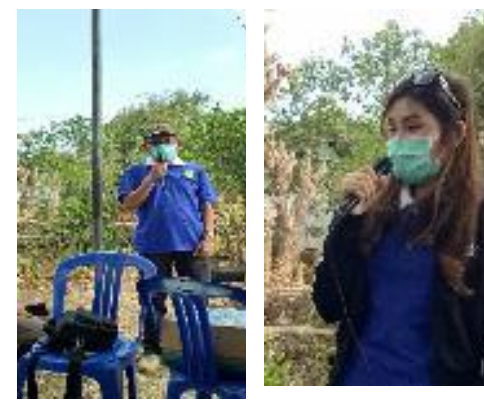

Gambar 3. Penyaji Materi kegiatan

Sesi 1. K3 pada bidang kesehatan bagi pekerja sektor informal pada saat pandemi covid 2019 oleh Dr. Anderias Umbu Roga, M.Kes

Pada sesi ini disosialisasikan pentingnya kesehatan dan keselamatan kerja dalam aktivitas pekerjaan yang mana dikerjakan oleh para pekerja zona informal dan melakukan karakter perilaku kebersihan dan kesehatan sesuai pedoman kesehatan dan keselamatan kerja dalam pencegahan penularan covid 2019. Apa dan bagaimana aktivitas yang sesuai dan tidak sesuai serta aturan yang harus ditaati oleh pekerja berdasarkan K3 bagi kesehatan. Setelah materi juga dilakukan tanya jawab dan diskusi dari para peserta pengabdian masyarakat.

\section{Sesi 2. Pencegahan Covid dengan 3 M oleh dr. Teacher Manalu, S.Ked}

Pada sesi ini dijelaskan 3 cara pencegahan covid 2019, dalam melakukan aktivitas di mana saja hendaknya menggunakan Masker guna mencegah kontak secara langsung atau tidak langsung dari cemaran virus covid 2019 yang berada di udara. Selanjutnya secara singkat disampaikan untuk sering melakukan pembersihan lengan dan tangan dengan menggunakan air mengalir dan juga memberikan sabun pada lengan dan tangan dengan cara menyapuh atau meletakkan sabun setelah itu dioleskan secara merata selama beberap menit lalu dicuci dengan air besih mengalir serta selalu melakukan penjagaan diri dengan memberikan renggang jarak dari kontak dengan orang lain minimal jarak satu meter.

Penelitian dan kajian tentang penyakit infeksi saluran pernapasan seperti flu, influenza, influenza-like illness, dan penyakit yang disebabkan oleh virus pada manusia tidak termasuk selain corona virus disease 2019 memperlihatkan hasil dan data yang mana menjelaskan bahwa pemakaian ataupun pemasangan masker medis dapat menghindarkan penularan dan perluasan tetes ludah atau droplet infeksi dari orang yang terjangkit virus ataupun orang yang mengalami pelemahan tubuh karena infeksi, dan termasuk gejala yang dialami penderita berupa simtomatik (pengendalian sumber) kepada orang lain dan adanya proses pengotoran atau pencemaran dari lingkungan akibat tetes-tetes ludah yang dikenal sebagai droplet [20], [21].

Hasil dan data yang akurat atau Bukti yang masih perlu kajian lagi memberikan petunjuk bahwa masker medis memiliki manfaat yang dapat memberikan proteksi terhadap paparan virus apabila dikenakan oleh orang sehat yang berada di kawasan perumahan, utamanya proteksi dari penderita yang terpapar ataupun apabila dikenakan pada kawasan ramai yang menghadirkan banyak orang seperti banyaknya orang yang melakukan aktivitas di luar rumah secara bersamaan dalam satu kawasan [22], [23], [24].

\section{Sesi 3. Pola Hidup Sehat dan Makanan bergizi untuk menjaga imunitas tubuh dari penularan Covid 2019 oleh dr. Maria, S.Ked}

Pada sesi ini dijelaskan karakter untuk melakukan pola hidup sehat diantaranya sering membersihkan tubuh dengan cara mandi teratur 2 kali sehari setelah mengadakan aktivitas luar rumah ataupun aktivitas lain, sering membersihkan rumah dan tempat tidur setiap hari, menjaga sanitasi lingungan rumah dari sampah dan lingkungan yang kotor, juga menerapkan pola makanan bergizi 
dengan mengkonsumsi pangan yang bergizi, sering makan sayur-sayuran dan buah-buahan, dan juga melakukan aktivitas gerakan tubuh secara teratur berupa gerak jalan atau aktivitas gerakan tubuh dilakukan setiap hari atau tiap hari Jumat, Sabtu dan Minggu atau tiga kali seminggu sesuai waktu yang tersedia selama 30 menit, dapat berupa jalan kaki selama 30 menit ataupun melakukan gerakan badan selama 30 menit di tempat terbuka dan tidak kontak dengan banyak orang, yang mana untuk memperkuat imunitas fisik dan memberikan proteksi imunitas sehingga tubuh tidak mudah tertular penyakit.

Sesi 4. Penyerahan bantuan Sembako, Obatobatan dan Vitamin, Masker dan Handsanitizer bagi pekerja informal oleh Dr. Muntasir, S.Si, Apt. M.Si

Pada sesi ini dilakukan pemberian bantuan sembako, obat-obatan, vitamin, masker dan handsanitizer bagi pekerja sektor informal sebanyak 25 paket. Penerima dari bantuan sosial kemanusiaan ini adalah hasil dari pengumpulan dana secara sukarela dari hasil kerja tim pada saat penggalangan dana di departemen atau program studi baik dari dosen maupun dari mahasiswa yang memberikan secara sukarela dana sehingga dapat tersedia paket sembako.
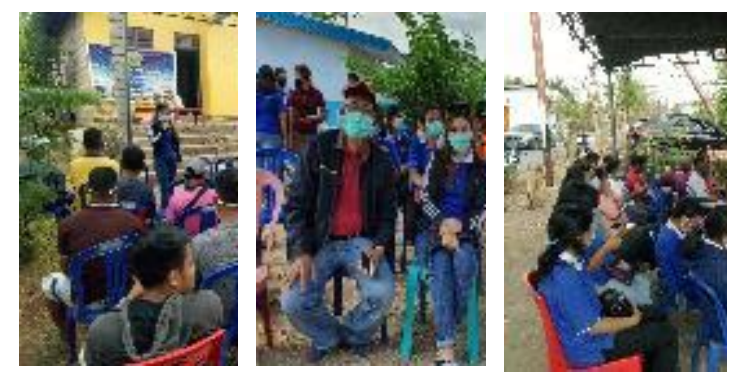

Gambar 4. Peserta mitra sasaran dan Tim pelaksana mengikuti penjelasan materi oleh penyaji
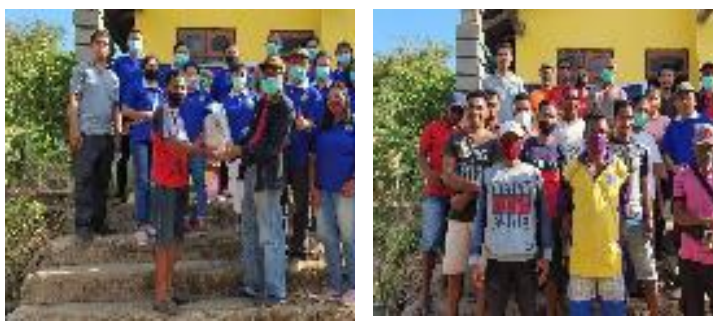

Gambar 5. Panitia pelaksana dan Mitra Peserta sasaran mendapatkan bantuan Sembako dan kelengkapan masker dan handsaniter secara simbolis

Target kegiatan Peserta sebanyak 25 orang dengan Tim Pelaksana 6 dosen dan didukung oleh Mahasiswa sebanyak 10 mahasiswa. Kegiatan ini juga dilakukan pengawasan dan penilaian kegiatan berupa evaluasi penilaian untuk melihat adanya feedback sikap, pengetahuan dan kemampuan peserta akan materi penyuluhan dan sosialisasi dari penceramah dengan memberikan penilaian tertutup dan meminta tanggapan peserta.

Pada pengmas ini dilakukan pengukuran pre test dan post test penguasaan peserta selama kegiatan pengmas antara lain tingkat pemahaman, sikap dan kemampuan softskill peserta.

Tabel 1. Pemahaman dan softskill para pekerja informasi pada pengmas

\begin{tabular}{|c|c|c|c|c|c|c|}
\hline \multirow{3}{*}{ Aktivitas yang diukur } & \multicolumn{6}{|c|}{ Aspek Penilaian } \\
\hline & \multicolumn{3}{|c|}{ Sebelum } & \multicolumn{3}{|c|}{ Setelah } \\
\hline & B & $\mathrm{C}$ & $\mathrm{K}$ & B & $\mathrm{C}$ & $\mathrm{K}$ \\
\hline \multicolumn{7}{|c|}{ Pemahaman materi Covid 2019} \\
\hline $\begin{array}{l}\text { a. Materi penyuluhan } \\
\text { covid }\end{array}$ & 20 & 30 & 50 & 90 & 5 & 5 \\
\hline $\begin{array}{l}\text { b. Penguasaan materi } \\
\text { penyuluhan }\end{array}$ & 10 & 50 & 40 & 95 & 5 & 0 \\
\hline \multicolumn{7}{|l|}{ Softskill PHBS } \\
\hline Bahan PHBS & 20 & 40 & 40 & 100 & 0 & 0 \\
\hline $\begin{array}{ll}\text { b. } & \text { Penguasaan cuci } \\
\text { tangan sesuai } \\
\text { pedoman PHBS }\end{array}$ & 10 & 30 & 50 & 90 & 10 & 0 \\
\hline
\end{tabular}

Pada Tabel 1 tersebut memperlihatkan aspek penilaian pengmas, khususnya aspek pemahaman berupa keinginan akan tahu dan softskill kebersihan dan kesehatan utamanya PHBS sebelum dilakukan pelatihan, memberikan hasil yang belum memuaskan dengan penilaian $50 \%$ tingkat penguasaan materi masih dalam penilaian yang kurang dari semua peserta. Setelah dilakukan pemberian materi dan sosialisasi serta penyuluhan pada pelatihan memberikan penilaian yang sangat baik dimana 90\% menunjukkan baik. Seluruh peserta penyuluhan dan sosialisasi sebanyak 25 memberikan aktivitas aktif mengikuti pelatihan, baik dalam bertanya maupun pada saat diskusi.

Pemahaman ataupun kemampuan mengetahui berupa aspek keinginan akan tahu dan softskill adalah indikator pengorganisasian dan memberdayakan kelompok, Pemahaman ataupun kemampuan mengetahui berupa Tingkat ingin tahu dan softskill meningkat ketanggapan dayaguna peserta didik dan pelatihan. Aspek peningkatan dayaguna agar lebih berdaya erat hubungan dengan aspek keterampilan dan adanya motivasi orang di sekitarnya [25]. Tingkat Pemahaman ataupun kemampuan mengetahui berupa Pengetahuan dan softskill berupa keterampilan yang kurang merupakan salah satu aspek bagi seseorang untuk mendapatkan ketanggapan agar diberdayakan [26]. Perorangan maupun kelompok akan melakukan kegiatan dan cermat memberikan tanggapan fisik dalam bentuk tindakan yang efektif dan efisien 
karena didkung oleh adanya pemahaman dan softskill terukur [27].

Output yang dapat dilihat pada penyuluhan dan sosialisasi ini yaitu Pemahaman ataupun keinginan tahu berupa Pengetahuan dan softskill peserta pengmas pekerja informal memberikan penilaian tingkat sangat memuaskan dari 25 peserta ini baik secara perorangan dan kelompok melakukan karakter kebersihan dan kesehatan.

Tindak lanjut dari aktivitas pengabdian masyarakat ini diharapkan pihak program studi S2 IKM dapat melakukan aktivitas pengabdian masyarakat dengan melibatkan kelompok masyarakat lainnya. Hasil penilaian akhir memperlihatkan pengabdian Masyarakat berupa solusi dalam bentuk aktivitas proteksi, penanganan serta mitigasi cermat terhadap karakter kesehatan dan kebersihan utamanya perilaku hidup bersih dan sehat dan bantuan kemanusiaan berupa pemberian sembako bagi pekerja sektor informal untuk tetap mampu melakukan produktivitas pada saat situasi dan kondisi Pandemi Covid 2019 di Kelurahan Lasiana Kota Kupang telah menunjukkan dan memberikan hasil yang lebih baik dan memuaskan, walaupun terdapat kendala dan persoalan di luar perencanaan seperti kendala lapangan. Adanya hubungan kerja yang baik oleh semua tim pelaksana dan output dapat memberikan manfaat bagi pekerja zona informal.

Respon dari mitra terutama pekerja zona informal yang berdomisili di kelurahan Lasiana menunjukkan antusias yang sangat memuaskan dengan respon warga pada keterlibatan dalam penilaian kegiatan sebelum pelaksanan dan sesudah pelaksanaan pengabdian masyarakat. Sebagai tindak lanjut berupa saran yang dapat diberikan untuk pelaksanaan pengabdian dan aktivitas berikutnya yaitu adanya aktivitas keberlanjutan dalam bentuk melakukan kunjungan rumah ke rumah para pekerja informal dengan protokol kesehatan ketat secara berkelanjutan oleh tim setelah program ini berakhir. Kunjungan rumah ke rumah para pekerja informal dimaksudkan agar mitra memiliki keinginan dan kemauan untuk melaksanakan karakter perilaku kebersihan dan kesehatan dengan prinsip hidup sehat terutama pola hidup bersih, makan makanan bergizi, olah raga teratur dan tidak merokok. Selanjutnya aktivitas ini perlu dimasyarakatkan agar diaplikasikan ditempat lain dengan pola kegiatan yang sama. Diharapkan kegiatan seperti ini di tempat lain dengan jumlah peserta yang lebih besar lagi dengan mengikuti protokol kesehatan dalam mencegah penularan dan infeksi Covid 2019. Motivasi bagi keluarga, kelompok masyarakat pekerja sektor informal untuk tetap menjaga diri untuk melakukan karakter utamanya perilaku kebersihan dan kesehatan yaitu hidup bersih dan sehat (PHBS) bagi pekerja zona informal untuk tetap produktif pada saat situasi dan kondisi Pandemi Covid 2019 di Kelurahan Lasiana Kota Kupang.

\section{SIMPULAN DAN SARAN}

Pengabdian masyarakat ini merupakan pemberdayaan kelompok dan masyarakat dilakukan melalui penyuluhan dan penguatan karakter perilaku kebersihan dan kesehatan bagi pekerja sektor informal untuk tetap produktif pada saat situasi dan kondisi Pandemi Covid 2019 di Kelurahan Lasiana Kota Kupang telah dilakukan sesuai metode yang telah diuraikan dalam pengabdian ini.

Luaran kegiatan berupa pemahaman dan pengetahuan dan serta softskill bagi para pekerja sektor informal yang terdampak Covid-2019 utamanya para kuli bangunan dan para pekerja yang tidak tetap, untuk melakukan penguatan karakter perilaku kebersihan dan kesehatan dengan mendapatkan informasi dan sosialisasi tentang penguatan karakter perilaku kebersihan dan kesehatan bagi pekerja sektor informal untuk tetap melakukan produktivitas dan adanya pemahaman akan dampak negatif dan resiko yang ditimbulkan apabila tidak melakukan penguatan karakter perilaku kebersihan dan kesehatan bagi pekerja sektor informal. Juga adanya bantuan sosial kemanusian dari tim pelaksana.

\section{UCAPAN TERIMA KASIH}

Tim Pelaksana program kemitraan masyarkaat berupa Pengabdian Masyarakat Program Studi S2 IKM Undana memberikan penghargaan dan Terima kasih kepada semua pihak yang memberikan dukugan moril, material dan, khususnya pihak departemen prodi S2 IKM dan Pimpinan Pascasarjana Undana yang telah memberikan amanah dan tanggung jawab untuk melaksanakan kegiatan ini serta masyarakat kelurahan Lasiana Kota Kupang aktif berpartisipasi pada PKM ini.

\section{DAFTAR PUSTAKA}

[1]. Muntasir M. Upaya peningkatan kondisi tetap sehat bagi pekerja informal di saat wabah pandemi covid 19. 2020;0016087004.

[2]. https://nasional.kontan.co.id/news/kemenake r-validasi-17-juta-data-pekerja-yangterkena-phk- selama-pandemi-covid-19. 2019:2019.

[3]. Siahaineinia HE, Bakara TL. Persepsi Masyarakat Tentang Penggunaan Masker Dan Cuci Tangan Selama Pandemi Covid-19 Di Pasar Sukaramai Medan. Wahana Inov J Penelit dan Pengabdi Masy UISU. 2020;9(1):173-176.

https://jurnal.uisu.ac.id/index.php/wahana/ar ticle/view/2874.

[4]. Sari D. Fenomena Ekonomi Dan 
Perdagangan Indonesia Di Masa Pandemi Corona Virus Disease-19 ( Covid-19). J Akunt dan Investasi. 2020;4(1):81-93. http://ejournal.unira.ac.id/index.php/jurnal_a ktiva/article/view/840.

[5]. Zhu H, Wei L, and Niu P. The novel coronavirus outbreak in Wuhan CGHR, Https://doi.org/10.1186/s41256-020-00135-6 P 2020;5(1). Https://Www.Who.Int/HealthTopics/Coronavirus\#Tab=Tab_1. 2020; https://gh(April):1-16.

[6]. https://nasional.kompas.com/read/2020/03/0 3/06314981/fakta-lengkap-kasus-pertamavirus- corona-di-indonesia?page=all. 2020:6314981.

[7]. Van Rhee JA. Covid. Physician Assist Clin. 2021;IV(2):240-252.

doi:10.1016/j.cpha.2021.01.002

[8]. Sayrani LP. Sektor Informal Dan Kontribusinya Dalam Kehidupan SosialEkonomi Warga Kota Kupang Informal Sector and Its Contributions for Citizen of Kupang City in Socio-Economic Lives. (1):113.

[9]. BPN. Peran Sektor Informal sebagai Katup Pengaman Masalah Ketenagaankerjaan. Badan Perenc Pembang Nas. 2020:1. https://www.bappenas.go.id/files/3513/5027/ 3734/kajian-peran-sektor-

informal2010090310304327490_20110518 101103_3050_0.pdf.

[10]. Publik JA. Informal Sector and Local Government Revenue : the Contribution of Street Vendors. None. 2014;11(1):25-35.

[11]. Rolis MI. Sektor Informal Perkotaan Dan. $J$ Sosiol Islam. 2013;3(2):93-111.

[12]. Gunawan BT. Pengaruh Pemilihan Kepala Daerah Terhadap Pasar Tenaga Kerja: Analisis Sektor Formal Dan Informal Level Kabupaten/Kota Di Pulau Jawa. Kaji Ekon dan Keuang. 2018;2(2):149-161. doi:10.31685/kek.v2i2.263

[13]. Muntasir M, Weraman P. Pengurangan Kadar Minyak Pada Abon Ikan Produksi Savitri Dan Tiaras Dengan Penerapan Alat Peniris Serbaguna Di Kota Kupang. JATI EMAS (Jurnal Apl Tek dan Pengabdi Masyarakat). 2018;2(2):20. doi:10.36339/je.v2i2.147

[14]. Kemdikbud. Visi Misi \& Tujuan. Direktorat Pembin SMK Direktorat Jenderal Pendidik Dasar dan Menengah Kementeri Pendidik dan Kebud. 2013:Konten. https://psmk.kemdikbud.go.id/konten/1/visimisi-dan-tujuan.

[15]. Muntasir M, Prilmayanti S. Aplikasi Teknologi Tepat Guna pada Pembuatan Kue Donat, Kue Roti dan Roti Goreng pada Mitra Usaha Roti Sari dan Dian Jaya Kota Kupang.
JATI EMAS (Jurnal Apl Tek dan Pengabdi Masyarakat). 2017;1(2):89. doi:10.36339/je.v1i2.58

[16]. Muntasir M, Purnawan S, Syahdan M. Penerapan Alat Peniris Serbaguna Model Silinder Sistem Sentrifuse Untuk Meningkatkan Mutu Dan Higienis Produk Kerupuk Jagung Kelimutu Sikumana Kota Kupang. JATI EMAS (Jurnal Apl Tek dan Pengabdi Masyarakat). 2018;2(1):50. doi:10.36339/je.v2i1.110

[17]. Sahdan M, Purnawan S, Muntasir M, Rarindo $\mathrm{H}$, Awaluddin SP. Penerapan Mesin Pengaduk Adonan Dan Etalase Produk Pada Usaha Pembuatan Kue Ulenan Dan Donat Di Pasar Tradisional Penfui Kota Kupang. JATI EMAS (Jurnal Apl Tek dan Pengabdi Masyarakat). 2018;2(2):28 doi:10.36339/je.v2i2.148

[18]. Weraman P, Muntasir M, Jutomo L, Harijono H. Alat Pengering Model Rak Bersusun Sistem Kolektor Plat Datar Sumber Energi Panas Matahari Untuk Meningkatkan Mutu Dan Higienis Produk Industri Kecil Kerupuk Dan Jagung Marning Usaha Sima Indah Kupang. JATI EMAS (Jurnal Apl Tek dan Pengabdi Masyarakat). 2019;3(1):88. doi:10.36339/je.v3i1.192

[19]. Prabandari F. Upaya Peningkatan Derajat Kesehatan Melalui Screening. 2021;2(1):387-391.

[20]. Canini L, Andréoletti L, Ferrari P, et al. Surgical mask to prevent influenza transmission in households: A cluster randomized trial. PLoS One. 2010;5(11):1-6. doi:10.1371/journal.pone.0013998

[21]. MacIntyre CR, Zhang Y, Chughtai AA, et al. Cluster randomised controlled trial to examine medical mask use as source control for people with respiratory illness. $B M J$ Open. 2016;6(12). doi:10.1136/bmjopen2016-012330

[22]. Jefferson T, Del Mar CB, Dooley L, et al. Physical interventions to interrupt or reduce the spread of respiratory viruses. Cochrane database Syst Rev. 2020;11:CD006207. doi:10.1002/14651858.CD006207.pub5

[23]. Cowling BJ, Chan KH, Fang VJ, et al. Facemasks and hand hygiene to prevent influenza transmission in households: A cluster randomized trial. Ann Intern Med. 2009;151(7):437-446. doi:10.7326/00034819-151-7-200910060-00142

[24]. Barasheed O, Almasri N, Badahdah A-M, et al. Pilot Randomised Controlled Trial to Test Effectiveness of Facemasks in Preventing Influenza-like Illness Transmission among Australian Hajj Pilgrims in 2011. Infect 
Disord - Drug Targets. 2014;14(2):110-116. doi:10.2174/1871526514666141021112855

[25]. Brodsky AE, Cattaneo LB. A Transconceptual Model of Empowerment and Resilience: Divergence, Convergence and Interactions in Kindred Community Concepts. Am J Community Psychol. 2013;52(3-4):333-346. doi:10.1007/s10464013-9599-x

[26]. Phan L. Measuring Women's Empowerment at Household Level Using DHS Data of Four
Southeast Asian Countries. Soc Indic Res. 2016;126(1):359-378. doi:10.1007/s11205015-0876-y

[27]. Muntasir M, Nur ML, Wijaya PC. PKM Diseminasi Informasi Kesehatan Bahaya Penyalahgunaan Napza Pada Remaja Di SMPN 16 Kelas 8 Kota Kupang Provinsi NTT. JATI EMAS (Jurnal Apl Tek dan Pengabdi Masyarakat). 2019;3(2):212. doi:10.36339/je.v3i2.255 